\title{
Causes of mortality of harbor porpoises Phocoena phocoena along the Atlantic and Pacific coasts of Canada
}

\author{
Heather Fenton ${ }^{1,6}$, Pierre-Yves Daoust ${ }^{1, *}{ }^{,}$María J. Forzán ${ }^{1}$, Raphaël V. Vanderstichel ${ }^{2}$, \\ John K. B. Ford ${ }^{3}$, Lisa Spaven ${ }^{3}$, Stéphane Lair ${ }^{4}$, Stephen Raverty ${ }^{5}$ \\ ${ }^{1}$ Canadian Wildlife Health Cooperative, Department of Pathology and Microbiology, Atlantic Veterinary College, \\ University of Prince Edward Island, 550 University Avenue, Charlottetown, PE C1A 4P3, Canada \\ ${ }^{2}$ Canadian Wildlife Health Cooperative, Department of Health Management, Atlantic Veterinary College, \\ University of Prince Edward Island, 550 University Avenue, Charlottetown PE, C1A 4P3, Canada \\ ${ }^{3}$ Pacific Biological Station, Fisheries and Oceans Canada, 3190 Hammond Bay Road, Nanaimo, BC V9T 6N7, Canada \\ ${ }^{4}$ Réseau canadien pour la santé de la faune, Faculté de médecine vétérinaire, Université de Montréal, 3200 rue Sicotte, \\ Saint-Hyacinthe, QC J2S 2M2, Canada \\ ${ }^{5}$ Canadian Wildlife Health Cooperative, Animal Health Branch, British Columbia Ministry of Agriculture, \\ Animal Health Centre, 1767 Angus Campbell Road, Abbotsford, BC V3G 2M3, Canada \\ ${ }^{6}$ Present address: Southeastern Cooperative Wildlife Disease Study, Department of Population Health, \\ College of Veterinary Medicine, University of Georgia, Wildlife Health Building, 589 D. W. Brooks Drive, Athens, GA 30602, USA
}

\begin{abstract}
There is increasing public interest in the overall health of the marine environment. Harbor porpoises Phocoena phocoena have a coastal distribution, and stranded animals function as sentinels for population and ecosystem health. The goal of this retrospective study was to join datasets from the western Atlantic and eastern Pacific coasts of Canada to investigate causes of morbidity and mortality in this species. A total of 241 necropsy records were reviewed including 147 (61\%) from the Pacific region and 94 (39\%) from the Atlantic region from 1988 to 2011 . A cause of death could be determined with confidence in 118 (49\%) of these cases. Of these 118 cases, the leading cause of mortality for both regions, together and separately, was infectious disease. In the Pacific region, this was followed by traumatic and anthropogenic causes, whereas in the Atlantic region, it was followed by emaciation/starvation, mortality of dependent calves, and anthropogenic causes. Pathogens of potential zoonotic significance or indicative of environmental contamination, e.g. Salmonella sp. and Cryptococcus gattii, were identified. Numerous parasitic species were observed within the lungs, liver, stomach, middle ear, and subcutaneous tissues, although they were usually interpreted as incidental findings. Anthropogenic causes may be underrepresented as they are notoriously difficult to diagnose with certainty, thereby making up a proportion of the 'unknown causes of death' (51\%) category. Improved standardization of data collection and documentation is required to better understand harbor porpoise and ecosystem health.
\end{abstract}

KEY WORDS: Harbor porpoise $\cdot$ Phocoena phocoena $\cdot$ Cetacean $\cdot$ Stranding $\cdot$ Mortality $\cdot$ Disease $\cdot$ North America · Canada

\section{INTRODUCTION}

There is global interest in the use of marine mammals, particularly odontocetes, as sentinels for monitoring the health of ocean ecosystems (Bossart 2011).

*Corresponding author: daoust@upei.ca
Current knowledge of diseases of free-living marine mammals and of the complex and dynamic ecology of diseases within the marine ecosystem has been enhanced by (1) studies of recent outbreaks of morbillivirus infection causing large-scale mortality in 
cetaceans and pinnipeds (Di Guardo 2012, Duignan et al. 2014); (2) an increasing interest in emerging zoonotic diseases such as brucellosis and toxoplasmosis (Van Bressem et al. 2009); and (3) the potential role of cetaceans as sentinels for persistent organic pollutants in the environment (Kucklick et al. 2011). As it is often logistically challenging to study marine mammals in the wild, it is particularly important to maximize the information obtained during stranding events in order to establish normal life history parameters and monitor anthropogenic causes of morbidity or mortality, emerging infectious diseases, and population demographics (Geraci \& Lounsbury 2005). Analyses of causes of mortality of cetaceans have been reported from several regions of the world (Cornaglia et al. 2000, Parsons \& Jefferson 2000, Jauniaux et al. 2002, Camphuysen et al. 2008, McFee \& Lipscomb 2009, Bogomolni et al. 2010, Arbelo et al. 2013, van der Hoop et al. 2013, Lair et al. 2016).

The harbor porpoise is the smallest cetacean in Canadian waters and has a predominantly coastal distribution, making it an excellent sentinel of Canadian inshore and nearshore waters. Both the Atlantic and Pacific populations are listed as 'Species of Special Concern' by the Committee on the Status of Endangered Wildlife in Canada (http://www.cosewic. gc.ca/eng/sct6/index_e.cfm, [accessed December 2016]). In addition, the Atlantic population is listed as 'Threatened' under the Canadian Species at Risk Act (www.registrelep-sararegistry.gc.ca/default.asp?lang $=e n \& n=24 F 7211 \mathrm{~B}-1$, [accessed December 2016]), largely due to the high incidence of by-catch mortality from entanglement in gill-net fishing gear (Trippel et al. 1996). This cause of mortality has remained a concern despite reduced fishing efforts following the collapse of commercial groundfish fisheries in the North Atlantic in the early 1990s (Lawson et al. 2004, Lesage et al. 2004). Although the numbers of harbor porpoises entangled in fishing nets in the Gulf of St. Lawrence (Fontaine et al. 1994) and in the Bay of Fundy (Trippel et al. 1996) have been estimated in the past, analyses of other causes of morbidity and mortality of harbor porpoises in Canadian waters are limited (Norman et al. 2004). According to Nemiroff et al. (2010), disease (including acute or chronic infection, chronic trauma, and poor nutritional condition) was the main cause of mortality among harbor porpoises found stranded or dead in the Maritime region of Atlantic Canada (i.e. the provinces of New Brunswick, Nova Scotia and Prince Edward Island) between 1990 and 2008. On the basis of existing diagnostic datasets, the objectives of this study were to summarize the causes of morbidity and mortality of harbor porpoises in the Atlantic and Pacific regions of Canada and to determine whether significant differences exist in these causes between the 2 regions.

\section{MATERIALS AND METHODS}

Animals from the Atlantic region of Canada were found along shores of Québec and the Maritime provinces $\left(44-47^{\circ} \mathrm{N}, 59-68^{\circ} \mathrm{W}\right)$, whereas those from the Pacific region were found along the coast of British Columbia $\left(48-54^{\circ} \mathrm{N}, 122-133^{\circ} \mathrm{W}\right)$. All necropsies in the Atlantic region were performed from 1988 to 2011 by pathologists at the Atlantic Veterinary College, University of Prince Edward Island, Charlottetown, Prince Edward Island, or at the Faculté de médecine vétérinaire, Université de Montréal, SaintHyacinthe, Québec. Necropsies in the Pacific region were performed from 1992 to 2010 either by wildlife biologists or veterinarians in the field or, more consistently after 2001, by pathologists at the Animal Health Centre, British Columbia Ministry of Agriculture, Abbotsford, British Columbia, where frozen carcasses were shipped and where laboratory analyses and final reports were completed. Necropsy and sample collection were based on a standard protocol modified according to the state of preservation of the carcass (Geraci \& Lounsbury 2005).

Table 1 provides a detailed list of the parameters and information recorded in the necropsy reports, although data were not available for all animals. Parameters included year and month when the carcass was found, location of carcass, body mass, standard length, blubber thickness at 3 sites, sex, relative age based on length, incident type (alive ashore [stranded], dead ashore [beached], dead in fishing net, floating dead at sea), state of carcass preservation, subjective body condition score, gross necropsy findings, histopathological findings, ancillary diagnostic tests, and morphologic diagnoses. For each necropsy report, a primary diagnosis was reached through consensus among 4 pathologists (H.F., P.Y.D., M.J.F., S.R.), who had carefully and independently reviewed morphologic findings and results of ancillary tests. For the purpose of this study, the primary diagnosis (cause of death) is the condition most likely to have initiated the series of events that resulted in the eventual death of the animal based on the information available. In contrast, secondary diagnoses, such as parasitism, include conditions that may or may not have contributed to the animal's death but were not considered the initial problem. The presence or absence of parasites in the lungs (nematodes), liver 
Table 1. Parameters recorded in the necropsy reports of harbor porpoises Phocoena phocoena found moribund or dead and submitted to Canadian veterinary diagnostic laboratories 1988-2011. Not all parameters were recorded for all animals

\begin{tabular}{|c|c|}
\hline Parameters & Details \\
\hline \multicolumn{2}{|l|}{ Year and month when found } \\
\hline Location & $\begin{array}{l}\text { British Columbia (Pacific region); Prince Edward Island, Nova Scotia, New } \\
\text { Brunswick, Québec (Atlantic region) }\end{array}$ \\
\hline \multicolumn{2}{|l|}{ Body mass (kg) } \\
\hline Standard length (m) & Straight line from tip of snout to tail notch \\
\hline $\begin{array}{l}\text { Blubber thickness at } 3 \text { individual sites } \\
\text { on the carcass }(\mathrm{mm})\end{array}$ & Dorsal, lateral, and ventral at axilla \\
\hline Sex & Male, female, or not recorded \\
\hline $\begin{array}{l}\text { Relative age based on length } \\
\text { (Van Bressem et al. 1998) }\end{array}$ & $\begin{array}{l}\text { Calf }(<1.18 \mathrm{~m}) \\
\text { Juvenile male }(<1.30 \mathrm{~m}) \\
\text { Juvenile female }(<1.40 \mathrm{~m}) \\
\text { Adult male }(>1.30 \mathrm{~m}) \\
\text { Adult female }(>1.40 \mathrm{~m}) \text {, or with evidence of sexual maturity such as lactation } \\
\text { or pregnancy }\end{array}$ \\
\hline Incident type & $\begin{array}{l}\text { Alive ashore (stranded) } \\
\text { Dead ashore (beached) } \\
\text { Dead in a fishing net } \\
\text { Floating dead at sea }\end{array}$ \\
\hline State of carcass preservation & Fresh, moderately decomposed, or autolyzed \\
\hline Subjective body condition score & $\begin{array}{l}\text { Good, moderate, or poor, based mainly on relative degree of convexity or con- } \\
\text { cavity of epaxial muscle mass and, to a lesser extent, on overall thickness of } \\
\text { blubber }\end{array}$ \\
\hline \multicolumn{2}{|l|}{ Gross description of pathological findings } \\
\hline \multicolumn{2}{|l|}{ Histological description of tissues sampled } \\
\hline Ancillary diagnostic tests & $\begin{array}{l}\text { Virology, bacteriology, mycology, parasitology, toxicology, immunohistochem- } \\
\text { istry, polymerase chain reaction (PCR), performed as required based on } \\
\text { gross and histopathological examination of the carcass }\end{array}$ \\
\hline One or more morphologic diagnoses & $\begin{array}{l}\text { Determined by a trained wildlife pathologist (either the one who performed } \\
\text { all of the diagnostic testing or, when the necropsy was performed by a bio- } \\
\text { logist or non-specialized veterinarian, the one who examined the tissues } \\
\text { histologically) }\end{array}$ \\
\hline
\end{tabular}

(trematodes), stomach (nematodes), pterygoid sinuses (associated with the middle/inner ear complex) (nematodes), and subcutaneous tissue (either plerocercoid cestode larvae or nematodes) was noted based on gross and/or microscopic findings.

The cause of death was assigned to one of the following categories adapted from Bogomolni et al. (2010) and Nemiroff et al. (2010):

(1) Infectious/inflammatory disease (viral, bacterial, fungal, parasitic, cause undetermined);

(2) Non-infectious disease (congenital anomaly, perinatal complications, toxicity);

(3) Emaciation/starvation (based mainly on relative degree of convexity or concavity of epaxial muscle mass and, to a lesser extent, on overall thickness of blubber), with no other clinically significant disease process identified;

(4) Dependent calves with no clinically significant disease process identified;
(5) Anthropogenic (e.g. gun-shot wound, entanglement in fishing gear);

(6) Trauma (interspecific aggression or exact cause undetermined);

(7) Mishap (animals found stranded or beached with no evident underlying disease process, and a history of adverse environmental conditions such as strong onshore wind and receding tide or the presence of a sand bar between shore and open water combined with the reported presence of prey species in the area);

(8) Unknown.

All statistical analyses were performed in Stata (version 14.1; StataCorp), unless otherwise stated. Fisher's exact tests were performed on categorical variables, for example between causes of death among the Atlantic and Pacific regions. Binomial probability tests were used to identify differences in proportions between 2 groups, for example between 


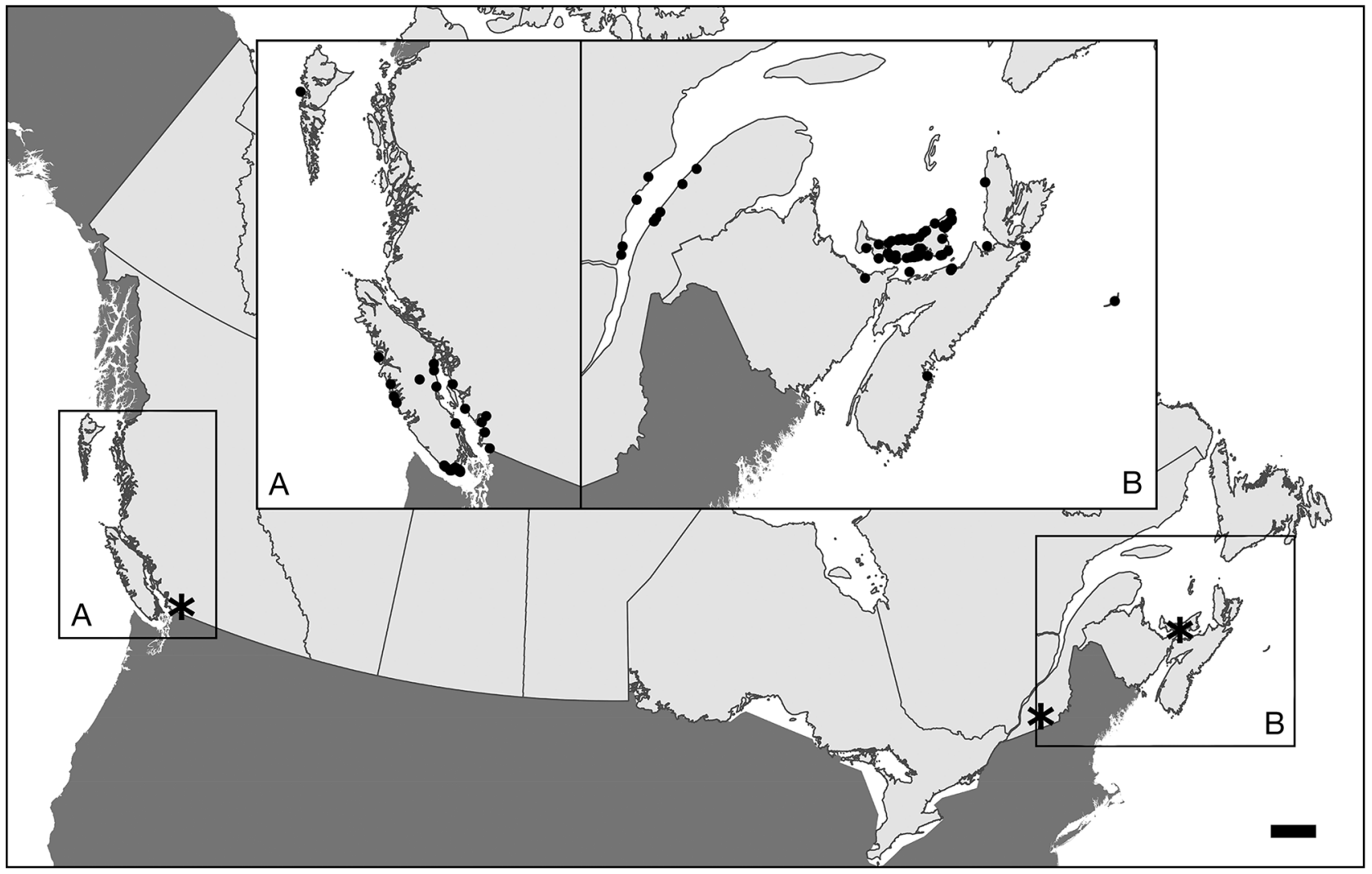

Fig. 1. Recorded locations of harbor porpoise Phocoena phocoena mortalities in (A) the northeastern Pacific region 1992-2010 $(\mathrm{n}=84)$ and $(\mathrm{B})$ the northwestern Atlantic region 1988-2011 $(\mathrm{n}=94)$. Asterisks indicate locations of the Canadian veterinary diagnostic laboratories that examined harbor porpoises. Scale bar $=300 \mathrm{~km}$

sexes or between regions for a specific cause of death. Finally, a simple linear regression was used to estimate the differences in mean blubber thickness (determined by averaging the dorsal, lateral, and ventral thicknesses at axilla) between the subjective body condition scores (BCS) (good, moderate, poor). Statistical significance was set at $\mathrm{p}<0.05$. Maps were generated with QGIS version 2.11 (www.qgis.org/ [accessed March 2016]).

\section{RESULTS}

\section{Location, sex, relative age, and incident type}

Of 241 necropsy reports reviewed, 147 (61\%) were from the Pacific region and 94 (39\%) were from the Atlantic region (including 56 that were also part of the study by Nemiroff et al. 2010 in that region). Because of the large expanse of coastline in both regions and the variable extent to which it is frequented by humans, it was not possible to determine what proportion of the total number of stranded har- bor porpoises was represented by those necropsied. All cases consisted of individual deaths; there were no instances of mass stranding. The approximate location was available for 84 porpoises from the Pacific region and for all porpoises from the Atlantic region (Fig. 1). The majority of animals in the Atlantic region $(84 / 94,89.3 \%)$ were found from May to September, when coastal water in this region is generally free of ice and when members of the public are also most likely to be on beaches. In the Pacific region, which is free of ice year-round, the month when the animal was found was available for only 29 of the 147 cases $(19.7 \%)$, and it was therefore not useful to assess monthly distribution. However, unpublished data from the Pacific region of the Canadian Department of Fisheries and Oceans suggest that $78 \%$ of porpoise mortalities were reported between April and September and $41 \%$ of these mortalities were reported in April-May alone.

The majority of carcasses were collected from British Columbia ( $\mathrm{n}=147,61.0 \%$ ) and Prince Edward Island ( $\mathrm{n}=72,29.9 \%$ ), while 12 carcasses were collected from Québec $(5.0 \%), 9$ from Nova Scotia 
(3.7\%), and 1 from New Brunswick (0.4\%). For both regions combined, there were equal proportions of males and females $(p=0.839)$, and the number of calves and juveniles was significantly higher than that of adults ( $p=0.007)$ (Table 2$)$; there was no statistically significant difference in age class or sex between the Atlantic and Pacific regions. The type of incident was recorded for 119 animals $(49.4 \%)$. Of these, the majority were found beached $(\mathrm{n}=94$, $79.0 \%)$, followed by dead at sea $(n=13,10.9 \%)$, and, in equal proportions, dead in a fishing net $(\mathrm{n}=6$, $5.0 \%)$ and stranded $(\mathrm{n}=6,5.0 \%)$. Stranded animals either died on their own or were promptly euthanized. There was no statistically significant difference in the distribution of types of incidents between the Atlantic and Pacific regions.

\section{Causes of death}

A cause of death could be determined in 118 of 241 cases $(49.0 \%$ ) (Table 3). Of these 118 cases, the leading cause of death for both regions, together and separately, was infectious disease. Among cases included in this category, 17 of 29 cases in the Pacific region and 3 of 16 cases in the Atlantic region were tested by polymerase chain reaction for infection by morbillivirus which, by targeting the immune system, can predispose to other infectious diseases. All cases were negative, and no microscopic lesions typical of morbilliviral infection, particularly intranuclear and/or intracytoplasmic inclusions bodies, were observed in any case.

In the Pacific region, infectious disease as a cause of death was followed by traumatic and anthropo-

Table 2. Sex and age breakdown of 241 harbor porpoises Phocoena phocoena submitted to Canadian veterinary diagnostic laboratories 1988-2011. Male and female porpoises equally represented within the dataset. Dataset was biased towards younger animals (juveniles and calves)

\begin{tabular}{|lcccc|}
\hline & $\begin{array}{c}\text { Pacific } \\
\text { region }\end{array}$ & $\begin{array}{c}\text { Atlantic } \\
\text { region }\end{array}$ & Total & $\%$ \\
\hline Sex & & & & \\
Female & 62 & 49 & 111 & 46 \\
Male & 63 & 44 & 107 & 44 \\
Not recorded & 22 & 1 & 23 & 10 \\
Age & & & & \\
Calf & 37 & 41 & 78 & 32 \\
Juvenile & 26 & 16 & 42 & 17 \\
Adult & 46 & 35 & 81 & 34 \\
Not recorded & 38 & 2 & 40 & 17 \\
\hline
\end{tabular}

genic causes, whereas in the Atlantic region it was followed by emaciation/starvation, mortality of dependent calves, and anthropogenic causes. Many more trauma cases were found in the Pacific region $(p=0.004)$, while the Atlantic region had many more cases of emaciation/starvation $(p=0.021)$ and dependent calves found dead $(p=0.012)$ and was the only region to have recorded mishaps. The proportions of porpoises included within the categories of infectious disease, non-infectious disease and anthropogenic causes were similar between regions. In both regions, non-infectious disease and, for the Atlantic region, mishap appeared to play a minor role in overall mortality. More harbor porpoises from the Pacific than from the Atlantic region were included in the 'unknown' category $(\mathrm{p}<0.001)$. The proportion of necropsy reports in which autolysis was mentioned as a factor that could have interfered with determination of a cause of death did not differ between the Pacific and Atlantic regions $\left(\chi^{2}=0.570, \mathrm{p}=0.450\right)$ or by province $\left(\chi^{2}=3.79, \mathrm{p}=0.285\right)$.

Nine of the 16 cases classified as 'Emaciation/starvation' were calves. Assuming a birth date around mid May (Westgate et al. 1997), the estimated age of 8 of these calves varied from recently born (teeth not erupted, umbilicus barely healed) to $6 \mathrm{mo}$; the time of death of one calf was not recorded. Eleven other calves (10 from recently born to estimated 4 mo old; 1 with no time of death recorded) had no clinically significant disease process identified and were not considered emaciated.

For both regions combined, mean blubber thicknesses were associated with the subjective BCS ( $\mathrm{n}=$ 85 ); they were on average $12.2,14.0$, and $20.0 \mathrm{~mm}$ for poor, moderate, and good BCS, respectively. While there was no statistically significant difference in blubber thickness between poor and moderate BCS $(p=0.673)$, there were significant differences between poor and good $(p<0.001)$, and moderate and good ( $p<0.001)$ BCS. No statistically significant difference was found in these parameters between the Atlantic and Pacific regions.

\section{Secondary diagnoses}

Of the 241 porpoises examined, $153(63.5 \%$; 95\% CI, 57.1-69.6\%) had some form of parasitism, which was associated with the cause of death in only 10 cases (Table 3). Adults represented a larger percentage of the animals parasitized $(77 / 153,50.3 \%)$ compared with juveniles $(30 / 153,19.6 \%)$, calves $(13 / 153$, $8.5 \%)$ and animals of unknown age (33/153, $21.6 \%)$ 
Table 3. Causes of death (primary diagnosis) (number of animals [percentage]) of 241 harbor porpoises Phocoena phocoena submitted to Canadian diagnostic laboratories 1988-2011 by region (western Atlantic and eastern Pacific). There were overall unequal distributions in the causes of mortalities between the Pacific and Atlantic regions (Fisher's exact test; $\mathrm{p}<0.001$ ), and binomial probability tests $(p)$ were used to identify regional differences for specific causes of death. ${ }^{*}$ Statistical significance at $p<0.05$

\begin{tabular}{|c|c|c|c|c|}
\hline Cause of death & $\begin{array}{l}\text { Pacific region } \\
\quad(\mathrm{n}=147)\end{array}$ & $\begin{array}{l}\text { Atlantic region } \\
\qquad(\mathrm{n}=94)\end{array}$ & $\begin{array}{c}\text { Total } \\
(\mathrm{n}=241)\end{array}$ & $\mathrm{p}$ \\
\hline Infectious & $29(20 \%)$ & $16(17 \%)$ & $45(18.7 \%)$ & 0.072 \\
\hline Viral $^{\mathrm{a}}$ & 1 & 0 & 1 & \\
\hline Bacterial $^{\mathrm{b}}$ & 6 & 1 & 7 & \\
\hline Parasitic $^{\mathrm{c}}$ & 3 & 7 & 10 & \\
\hline Fungal $^{\mathrm{d}}$ & 11 & 2 & 13 & \\
\hline Cause undetermined $^{\mathrm{e}}$ & 8 & 6 & 14 & \\
\hline Non-infectious & $2(1.3 \%)$ & $4(4.2 \%)$ & $6(2.5 \%)$ & 0.688 \\
\hline Congenital anomaly ${ }^{\mathrm{f}}$ & 1 & 1 & 2 & \\
\hline Perinatal complications & $1^{\mathrm{g}}$ & $1^{\mathrm{h}}$ & 2 & \\
\hline Saxitoxin intoxication ${ }^{\mathrm{i}}$ & 0 & 2 & 2 & \\
\hline Emaciation/starvation ${ }^{j}$ & $3(2 \%)$ & $13(13.8 \%)$ & $16(6.6 \%)$ & $0.021^{*}$ \\
\hline Dependent calves: no identifiable disease & $1(0.7 \%)$ & $10(10.6 \%)$ & $11(4.6 \%)$ & $0.012^{*}$ \\
\hline Anthropogenic & $12(8.1 \%)$ & $9(9.6 \%)$ & $21(8.7 \%)$ & 0.664 \\
\hline Gun-shot wound & 1 & 0 & 1 & \\
\hline Entanglement in fishing gear ${ }^{\mathrm{k}}$ & 11 & 9 & 20 & \\
\hline Trauma & $14(9.5 \%)$ & $2(2.1 \%)$ & $16(6.6 \%)$ & $0.004^{*}$ \\
\hline Interspecific aggression $^{1}$ & 5 & 0 & 5 & \\
\hline Cause undetermined & 9 & 2 & 11 & \\
\hline Mishap & $0(0 \%)$ & $3(3.2 \%)$ & $3(1.2 \%)$ & 0.250 \\
\hline Unknown & $86(58.5 \%)$ & $37(39.4 \%)$ & $123(51.0 \%)$ & $<0.001^{*}$ \\
\hline \multicolumn{5}{|c|}{$\begin{array}{l}{ }^{a} \text { Esophagitis caused by herpesvirus infection based on PCR analysis of fresh tissue samples; thought to have interfered with } \\
\text { swallowing }\end{array}$} \\
\hline \multicolumn{5}{|c|}{$\begin{array}{l}\text { bepticemia ( } 3 \text {; Photobacterium damselae, Streptococcus phocae, Vibrio parahemolytica), myocarditis (Salmonella ari- } \\
\text { zonae), pneumonia (Staphylococcus sciuri), peritonitis (Edwardsiella tarda), enteritis (Clostridium difficile) }\end{array}$} \\
\hline \multicolumn{5}{|c|}{$\begin{array}{l}{ }^{c} \text { Verminous pneumonia ( } 7 \text {; at least } 3 \text { of them complicated by secondary bacterial infection: Vibrio sp., E. tarda), enteritis } \\
\text { (unspecified helminths), hepatic trematodiasis (2) }\end{array}$} \\
\hline \multicolumn{5}{|c|}{$\begin{array}{l}{ }^{\mathrm{d}} \text { Generalized infection ( } 8 \text { caused by Cryptococcus gatti, } 1 \text { caused by Aspergillus fumigatus, } 1 \text { caused by a zygomycetous } \\
\text { fungus, } 1 \text { caused by an unidentified fungus), pneumonia ( } 1 \text { caused by a zygomycetous fungus, } 1 \text { caused by an unidenti- } \\
\text { fied fungus) }\end{array}$} \\
\hline \multicolumn{5}{|c|}{$\begin{array}{l}\text { e'Meningitis/meningoencephalitis ( } 4 \text {; all negative for Brucella sp. by PCR; only } 1 \text { tested by PCR for morbillivirus and found } \\
\text { negative, none of the } 4 \text { cases with microscopic lesions typical of morbilliviral infection, such as intranuclear and/or intra- } \\
\text { cytoplasmic inclusion bodies), pneumonia, pleuritis (2), peritonitis (4), polyserositis, metritis, endometritis }\end{array}$} \\
\hline \multicolumn{5}{|c|}{ IfInterventricular septal defect; hepatic hamartoma } \\
\hline \multicolumn{5}{|c|}{${ }^{9}$ Meconium aspiration syndrome in a neonate } \\
\hline \multicolumn{5}{|c|}{$\begin{array}{l}\text { hDystocia (female with intrauterine autolyzed near-term fetus, opened uterine cervix, and marked inflammation of the uter- } \\
\text { ine wall) }\end{array}$} \\
\hline \multicolumn{5}{|c|}{ ¿Based on same criteria as in Scarratt et al. (2013) } \\
\hline \multicolumn{5}{|c|}{ JIncluding 9 calves } \\
\hline \multicolumn{5}{|c|}{$\begin{array}{l}{ }^{\mathrm{k}} \text { Confirmed by the history in } 6 \text { animals; based on the presence of characteristic linear cutaneous indentations and abrasions } \\
\text { in } 12 \text { animals; in } 2 \text { animals, based on otherwise negative laboratory findings and on the nearby presence on shore of car- } \\
\text { casses of northern gannets Morus bassanus in good body condition and with fish in their stomach, a species commonly } \\
\text { affected by entanglement in fishing gear }\end{array}$} \\
\hline $\begin{array}{l}{ }^{1} \text { Based either on direct observation of pred } \\
\text { predation by killer whales (skin stripped off }\end{array}$ & on or smotherin & ziller whales or or & nce of charact & istic lesions of \\
\hline
\end{tabular}

( $\mathrm{p}<0.001)$. From the total number of submissions, $126(52.3 \%)$ had pulmonary nematodes, $102(42.3 \%)$ had hepatic trematodes, $54(22.4 \%)$ had gastric nematodes, $41(17.0 \%)$ had nematodes in pterygoid sinuses, and 16 (6.6\%) had blubber/subcutaneous parasites (either plerocercoid cestode larvae or nematodes). Parasite species identified included Pseudal- ius inflexus, Stenurus sp., Torynurus convolutus and Halocercus sp. in the lungs; Campula oblongata in the liver; Contracaecum sp. and Anisakis sp. in the stomach; Stenurus minor in pterygoid sinuses; and Phyllobothrium sp. and Crassicauda sp. in the blubber. Other parasites noted occasionally were Pseudalius inflexus within the right cardiac ventricle and 
major pulmonary blood vessels $(9 / 241,3.7 \%)$ and intestinal cestodes thought to be Diphyllobothrium sp. $(3 / 241,1.2 \%)$. There were no regional differences in the number of animals with some form of parasitism $(p=0.339)$, pulmonary nematodes $(p=0.509)$, gastric nematodes $(p=0.735)$, or hepatic trematodes $(p=0.505)$. The presence of blubber parasites was recorded more often in the Pacific region than in the Atlantic region $(\mathrm{n}=15$ and $\mathrm{n}=1$, respectively; $\mathrm{p}=$ 0.006). All of the nematodes within pterygoid sinuses were recorded in the Atlantic region; this anatomical location was not examined systematically in the Pacific region.

Salmonella sp. was isolated from 3 animals that died from an unrelated cause: Salmonella sp. group B from the small intestine, Salmonella sp. (serotype 1:4,12:a) from the lungs, and a non-serotyped Salmonella sp. from the lungs. Other bacterial species known to be opportunistic or primary pathogens in humans (Quinn et al. 2002) that were cultured from animals which died from an unrelated cause included Aeromonas sp., Erysipelothrix rhusiopathiae, Clostridium difficile, C. perfringens, Pasteurella multocida, Photobacterium damselae, Proteus sp., Staphylococcus epidermidis, and Vibrio sp.

\section{DISCUSSION}

Retrospective studies of causes of wildlife mortality carry a number of limitations, such as sampling biases and the difficulty of distinguishing primary from secondary diagnoses in the absence of any clinical history. However, such studies can provide valuable insight into the life history of the species involved, their habitat, baseline health parameters, and anthropogenic factors that may affect their survival. Male and female harbor porpoises were equally represented in this study, but there was a significantly higher proportion of sexually immature animals (juveniles and calves) compared to adults, which is consistent with previous reports for marine mammals (Barlow \& Boveng 1991). In the Atlantic region, Prince Edward Island was markedly overrepresented in terms of the number of harbor porpoises necropsied as compared to New Brunswick, Nova Scotia, and Québec. This was likely because the small size of the province allows easy delivery of carcasses to the diagnostic laboratory at the Atlantic Veterinary College, and compared to the other provinces, most of its shoreline is easily accessed by people, increasing the probability of carcass detection. We did not try to determine specifically whether reported cases of stranding were more likely to come from the vicinity of cities, although in the Pacific region the harbor porpoises submitted seemed to be predominantly clustered around highly populated centers such as Victoria and Vancouver, presumably because carcasses and stranded animals are more likely to be found and reported in such areas. In their study of cetacean strandings in the Canadian Maritime provinces, Nemiroff et al. (2010) briefly discussed the many factors that can influence the likelihood of stranding events being reported, such as proximity to large cities, higher concentrations of whales in rich feeding areas, and thus larger numbers of observers in these areas, and the proportion of accessible beaches in a particular region.

\section{Cause of death}

\section{Unknown}

A cause of death could not be determined with confidence in $123(51.0 \%)$ of the 241 cases reviewed. Autolysis was partly responsible for the undetermined results in some cases. An unknown proportion may also be attributed to anthropogenic causes since these can be difficult to diagnose with certainty. In particular, drowning from entanglement in fishing gear may leave little to no evidence, especially if even moderate autolysis has allowed deterioration of the skin surface, thus masking abrasions or small indentations caused by the nets.

In the Pacific region, the larger proportion of undiagnosed cases could be explained in part by inconsistent levels of examination and diagnostic evaluation in the early years up until 2001, when a better system for carcass response and collection was established, and possibly in general by provision of less information to the pathologists on the circumstances surrounding the animals' death. The reverse situation could explain the fact that all causes of mortality identified as mishap were from the Atlantic region, as these diagnoses depended on a detailed history of the circumstances surrounding the animals' death.

\section{Infectious disease}

Infectious diseases were the most commonly diagnosed cause of death for the Atlantic and Pacific regions, together and separately. Infectious diseases, particularly pneumonia (bacterial and parasitic), were also a leading cause of mortality in other populations of harbor porpoises previously studied (Baker 
\& Martin 1992, Siebert et al. 2001). Similarly, they are the most prevalent cause of mortality in the isolated population of beluga Delphinapterus leucas in the St Lawrence Estuary (SLE) (Lair et al. 2016) and a substantial cause of mortality in bottlenose dolphins Tursiops truncatus in coastal waters of South Carolina, USA (McFee \& Lipscomb 2009). However, it is possible that animals of coastal species such as harbour porpoises, belugas and bottlenose dolphins debilitated by an infectious disease seek shallower waters to reduce energetic demands of swimming and are thus more likely to be found after death than animals dying as a result of other causes.

Infectious causes of death in this study included those of a viral, bacterial, fungal, and parasitic nature. Of the bacteria identified, Vibrio sp., Photobacterium damselae, and Salmonella sp. are zoonotic and have been associated with previous exposure to fish (Harper 2002); Clostridium difficile generally resides in the large intestine of mammals (including humans), and therefore its presence can be an indication of fecal contamination of water, as is that of Salmonella sp. (Daoust \& Prescott 2007, Anderson et al. 2015).

Cryptococcosis, responsible for 8 of 13 cases of fatal fungal infection in this study, all from the Pacific region, is due to the basiodiomycetus yeast Cryptococcus gattii (formerly $C$. neoformans var. gattii) and can cause cutaneous, respiratory and neurological disease in immunocompromised hosts, including humans. The disease emerged in 1999 in humans and a variety of other species, including harbor porpoises, in southwestern British Columbia, largely within its coastal Douglas fir (Pseudotsuga menziesii) biogeoclimatic zone, highlighting the role that marine mammals can play as sentinels of environmental health (Duncan et al. 2006).

The potential role of environmental contaminants in causing immunosuppression, thus predisposing marine mammals to infectious disease, was not examined in this study. However, there is published evidence of an association between exposure to heavy metals and organic pollutants and increased susceptibility to infectious disease in harbour porpoises and other marine mammals (Bennett et al. 2001, Jepson et al. 2005, Reif et al. 2015, Lair et al. 2016).

\section{Non-infectious disease}

Non-infectious causes of death included congenital defects (cardiac malformation, hepatic hamartoma), perinatal complications (dystocia, meconium aspiration syndrome presumably resulting from dystocia), and saxitoxin poisoning. Cardiac anomalies have been previously reported in marine mammals (Gray \& Conklin 1974, Dennison et al. 2011). Poor maternal condition, in utero viral infection, or exposure to toxin, as well as chromosomal and genetic alterations have been suggested as possible causes that are well described in humans (Schoen \& Mitchell 2010). A hamartoma represents a benign, non-neoplastic cellular proliferation in a localized area that surpasses the normal growth of cells in that area and is presumed to be of congenital origin (Kusewitt 2012). Hamartomas have been reported in a California sea lion Zalophus californianus (Blankenship et al. 2008) and in a neonatal harbor seal Phoca vitulina exposed to polycyclic aromatic hydrocarbons (Harris et al. 2011). Dystocia has been documented as a cause of death in a variety of marine mammal species including harbor porpoises. Lair et al. (2016) observed a recent increase in occurrence of perinatal complications in the SLE beluga population and discussed the possible role of perinatal environmental stresses, nutritional stress, and endocrine-disrupting environmental contaminants as risk factors. Saxitoxin is a neurotoxin produced by dinoflagellates that is responsible for paralytic shellfish poisoning in humans and is capable of killing marine mammals (Geraci et al. 1989). The 2 porpoises killed by this toxin were from an episode identified in the St. Lawrence Estuary in 2008 that affected a large number of animals of various species (Scarratt et al. 2013). Although comprising a small percentage, the non-infectious causes of mortality found in the harbor porpoises examined in this study could potentially reflect a much larger impact of environmental toxins within the marine environment.

\section{Emaciation/starvation}

Evaluation of body condition in small and large whales is often based mainly on the appearance of the epaxial muscle mass; blubber thickness by itself is not considered a reliable indicator of this parameter, although we did see a positive correlation between mean blubber thickness and subjective BCS (Read 1990, Arbelo et al. 2013, Joblon et al. 2014).

Emaciation with no other clinically significant disease process was a common cause of mortality in the Atlantic region, which is consistent with similar studies from Europe (Jauniaux et al. 2002). The cause of this emaciation was unknown, but more than half of the animals were calves that were still dependent on their mother. Separation of mother and calf has been 
documented in other cetaceans in areas of high boating activity and could thus be considered a possible anthropogenic cause of mortality (Van Parijs \& Corkeron 2001). Fishing vessels are common in both regions included in this study, and the appearance of pleasure crafts in early summer coincides with the approximate birth date of harbor porpoises. In our study, there were more harbor porpoises classified in this category from the Atlantic than from the Pacific region, but the reason for this could not be determined.

Dependent calves: no identifiable disease

A specific cause of death could not be determined for 11 calves that had presumably been separated from, or abandoned by, their mother and had no identifiable disease process such as emaciation. Disorientation and eventual stranding by mishap may have occurred in some of them. Two of these 7 calves had recently been born. The capacity of a newborn animal to cope with sudden food deprivation can vary substantially among species. For example, the amount of fat present at birth in healthy bovine calves is enough to provide energy for at least $7 \mathrm{~d}$ of severe malnutrition in a thermoneutral zone (14$16^{\circ} \mathrm{C}$ ) (Schoonderwoerd et al. 1986). In contrast, a newborn piglet has very little fat available for mobilization and relies mainly on glycogen in liver and muscle as an endogenous source of energy (Mersmann 1974). It is unclear where the harbor porpoise fits in this spectrum. The marine environment where and when a harbor porpoise calf is born likely requires a major expenditure of energy for thermoregulation (Koopman 1998). It is therefore possible that the death of a newborn calf would result from acute calorie depletion combined with hypothermia. However, the category of emaciation/starvation included 2 recently born calves with marked atrophy of their epaxial muscle mass, indicating that some newborn harbor porpoises deprived of food may survive for some time on endogenous sources of energy. In the study of the SLE beluga population by Lair et al. (2016), the cause of death of the vast majority of dependent calves examined also could not be clearly determined.

Anthropogenic causes

Anthropogenic causes were among the main diagnosed causes of death in both regions and within the combined dataset. This is consistent with other studies that have shown that human factors, more specifically boat collisions and fisheries by-catch, are important causes of mortality in cetaceans, including harbor porpoises (Lawson et al. 2004, Lesage et al. 2004, Arbelo et al. 2013, van der Hoop et al. 2013). The overall impact of death from anthropogenic causes is likely underestimated in this study since some cases included in the 'trauma' category were suspected, but not proven, to have been caused by boat collision and since some cases included in the 'unknown' category may have resulted from drowning secondary to entanglement in fishing gear without leaving evidence of this in the carcass. Entanglement in fishing gear was the leading anthropogenic cause of death of harbor porpoises identified in both regions (20 of 21 cases), despite the fact that a conclusive diagnosis of entanglement can be difficult. Ideally, it requires a history of the animal being found within a fishing net or lesions such as linear cutaneous furrows, indentations or abrasions affecting the snout, flippers, and/or cranial part of the torso, and possibly evidence of recent ingestion of fish (Kuiken 1996).

\section{Trauma}

All suspected cases of predation were attributed to killer whales Orcinus orca and were from the Pacific region, corresponding to regional differences in the range and abundance of this species (Forney \& Wade 2006). Predation of harbor porpoises by sharks has been reported in the Atlantic region (Arnold 1972), but no such case was found in this study. Predation by grey seals Halichoerus grypus on harbor porpoises has been described in the southeastern North Sea (Leopold et al. 2015). This has been suspected, but not proven, to also happen in the Atlantic region.

Vessel strikes involving both small craft and large ships have been documented as a cause of mortality of marine mammals (Stone \& Yoshinaga 2000, van der Hoop et al. 2013). Although it may be difficult to distinguish collisions with boats from other forms of trauma, 2 harbor porpoises in this study had deep lacerations of the dorsal skin suggestive of propeller wounds (Laist et al. 2001). The cases of trauma of unknown origin could have been due to predation or to collision with boats, but also to aggression by whales of larger species (Baird 1998, Haelters \& Everaarts 2011, Larrat et al. 2012). 


\section{Parasitism}

Parasitism was a common incidental finding in harbor porpoises included in this study. Adults were parasitized more often than juveniles and calves, perhaps reflecting an increased likelihood of ingesting parasites from intermediate hosts with age (Measures 2001). Nematodes within pterygoid sinuses, in some cases identified as Stenurus minor, were reported only from the Atlantic region. This was likely because this anatomical location was not examined systematically in carcasses from the Pacific region. The pathological effects of this nematode are poorly known. Early reports associated heavy infection with stranding, presumably due to disruption of echolocation, but this has not been conclusively shown, in contrast to other middle ear parasites like the trematode Nasitrema sp. (Measures 2001).

Because of a long period of co-evolution, many parasites may be host-adapted, and infections are not necessarily associated with the cause of death (Anderson 1982). In particular, the clinical significance of pulmonary parasitism in odontocetes can be difficult to assess (Lair et al. 2016). Factors allowing pulmonary parasitism to progress to clinically significant disease, including complication by secondary bacterial infection, could be related to immunosuppression caused by organic pollutants, marine algal toxins, concurrent infection with viruses, or environmental stressors such as marine traffic and noise (Jepson et al. 2000, Bossart 2011, Rolland et al. 2012).

\section{CONCLUSIONS}

Overall, the leading known cause of mortality for harbor porpoises in Canadian waters was infectious disease, although anthropogenic causes were likely underestimated. Parasitism was commonly observed but was considered a secondary diagnosis in most cases, suggesting caution in interpreting parasitic infection as a significant cause of death. Previous reports of harbor porpoise mortality often indicate that the top 3 causes of death are emaciation, negative fisheries interactions, and infectious disease (Trippel et al. 1996, Jauniaux et al. 2002, Wright et al. 2013, Huggins et al. 2015).

Coastal ecosystems throughout the world have suffered extensively from a wide variety of human activities, since more than half of the world's human population resides within approximately $60 \mathrm{~km}$ of the coast (Kennish 2005). Moreover, there is published evidence of a correlation between occurrence of infectious diseases in harbor porpoises and burdens of environmental contaminants and their associated immunosuppressive effects (Bennett et al. 2001, Jepson et al. 2005). Being typically a coastal species, the harbor porpoise is more likely than other species to be exposed to contaminants and pollutogens of industrial and agricultural origin (Lafferty et al. 2004, Kennish 2005, Gibson et al. 2011, Barbosa et al. 2015). This may explain at least partly the relatively high proportion of infectious diseases identified in both regions in this study. However, determination of levels of environmental contaminants in animals included in this study was not attempted. A proper comparison of such levels between the east and west coasts would have required extensive methodology in order to take into account the multiplicity of factors (biological, regional, temporal) influencing the types, chemical profiles, and potential impact of these contaminants (Muir et al. 1996, Westgate et al. 1997). We are not aware of major differences in natural and humanrelated environmental conditions between waters of the east and west coasts of Canada that should have been considered in the interpretation of our results, except for the fact that, in contrast to the west coast, large water ways of the east coast are frozen in winter. The proportions of deaths from infectious disease were similar in both regions, thus reducing the likelihood of a differential influence of contaminants in these 2 regions.

The proportion of cases of entanglement in fishing gear was also similar in both regions. Negative interactions with fisheries are often considered the leading conservation threat for harbor porpoises and are often the only focus of mitigation measures (Trippel et al. 1999, Read et al. 2006, Gönener \& Bilgin 2009). While fisheries interactions undoubtedly play an important role in harbor porpoise mortality, this and other studies (Jauniaux et al. 2002, Hohn et al. 2013) show that other causes are involved and, in particular, demonstrate a knowledge gap regarding the overall impact of infectious diseases on populations of harbor porpoises.

The actual impact of each cause of death on populations of harbor porpoises cannot be predicted based on the current datasets. Nonetheless, considering the very low proportion of carcasses normally recovered from cetacean mortality events (1-2\% by some estimates; Brown 1975, Williams et al. 2011), observations of carcasses coming ashore represent a valuable opportunity to study the natural history of these animals and the diseases that may affect their populations. 
This study also indicates a need to better understand the pathogenesis of infectious diseases in marine mammals, including the potential contribution of immunosuppression and its various possible causes. The identification of various pathogens of zoonotic significance, some of them suggestive of fecal contamination of coastal waters, highlights the importance of health surveillance in marine mammals as sentinels of ocean health.

Acknowledgements. The authors extend their sincere gratitude to the following people and organizations for their assistance with this study: Deborah Austin, Donald Benoit, France Boily, Gary Conboy, Paul Cottrell, André Dallaire, Marion Desmarchelier, Chuck Gallison, Anna Hall, Chris Harvey-Clark, Martin Haulena, David Huff, Fred Kibenge, Sylvain Larrat, Ron Lewis, Scott McBurney, Shannon Martinson, Aleksija Neimanis, the Nova Scotia Marine Animal Response Society (Tonya Wimmer and Andrew Reid), and Fisheries and Oceans Canada.

\section{LITERATURE CITED}

Anderson CE, Haulena M, Zabek E, Habing G, Raverty S (2015) Clinical and epidemiologic considerations of Clostridium difficile in harbor seals (Phoca vitulina) at a marine mammal rehabilitation center. J Zoo Wildl Med 46:191-197

Anderson RC (1982) Host parasite relations and evolution of the Metastrongyloidea (Nematoda). Zoology 123:129-133

Arbelo M, Espinosa de los Monteros A, Herráez P, Andrada $M$ and others (2013) Pathology and causes of death of stranded cetaceans in the Canary Islands (1999-2005). Dis Aquat Org 103:87-99

Arnold PW (1972) Predation on harbour porpoise, Phocena phocena, by a white shark, Carcharodon carcharias. J Fish Res Board Can 29:1213-1214

Baird RW (1998) An interaction between Pacific white-sided dolphins and a neonatal harbor porpoise. Mammalia 62: 129-134

Baker JR, Martin AR (1992) Causes of mortality and parasites and incidental lesions in harbour porpoises (Phocoena phocoena) from British waters. Vet Rec 130:554-558

Barbosa L, Johnson CK, Lambourn DM, Gibson AK and others (2015) A novel Sarcocystis neurona genotype XIII is associated with severe encephalitis in an unexpectedly broad range of marine mammals from the northeastern Pacific Ocean. Int J Parasitol 45:595-603

Barlow J, Boveng P (1991) Modeling age-specific mortality for marine mammal populations. Mar Mamm Sci 7:50-65

Bennett PM, Jepson PD, Law RJ, Jones BR and others (2001) Exposure to heavy metals and infectious disease mortality in harbour porpoises from England and Wales. Environ Pollut 112:33-40

Blankenship B, Dold C, Jensen E, Smith C, Van Bonn W, Ridgway S (2008) Neuronal migration defect: a case of subcortical heterotopia in a California sea lion. Vet Pathol 45:412-416

Bogomolni AL, Pugilliares KR, Sharp SM, Patchett K and others (2010) Mortality trends of stranded marine mammals on Cape Cod and southeastern Massachusetts, USA, 2000 to 2006. Dis Aquat Org 88:143-155
Bossart GD (2011) Marine mammals as sentinel species for oceans and human health. Vet Pathol 48:676-690

* Brown SG (1975) Relation between stranding mortality and population abundance of smaller Cetacea in the northeast Atlantic Ocean. J Fish Res Board Can 32:1095-1099

Camphuysen CJK, Smeenk C, Addink M, van Grouw H, Jansen OE (2008) Cetaceans stranded in the Netherlands from 1998 to 2007. Lutra 51:87-122

Cornaglia E, Rebora L, Gili C, Di Guardo G (2000) Histological and immunohistochemical studies on cetaceans found stranded on the coast of Italy between 1990 and 1997. J Vet Med A 47:129-142

Daoust PY, Prescott JF (2007) Salmonellosis. In: Thomas NJ, Hunter DB, Atkinson CT (eds) Infectious diseases of wild birds. Blackwell Publishing Company, Hoboken, NJ, p 270-288

* Dennison SE, Van Bonn W, Boor M, Adams J, Pussini N, Spraker T, Gulland FMD (2011) Antemortem diagnosis of a ventricular septal defect in a California sea lion Zalophus californianus. Dis Aquat Org 94:83-88

* Di Guardo G (2012) Morbillivirus-host interaction: lessons from aquatic mammals. Front Microbiol 3:431

* Duignan PJ, Van Bressem MF, Baker JD, Barbieri M and others (2014) Phocine distemper virus: current knowledge and future directions. Viruses 6:5093-5134

Nouncan C, Schwantje H, Stephen C, Campbell J, Bartlett K (2006) Cryptococcus gatii in wildlife of Vancouver Island, British Columbia, Canada. J Wildl Dis 42:175-178

Fontaine PM, Barrette C, Hammill MO, Kingsley MCS (1994) Incidental catches of harbor porpoises (Phocoena phocoena) in the Gulf of St. Lawrence and the St. Lawrence River Estuary, Québec, Canada. Rep Int Whaling Comm 15(Spec):159-163

Forney KA, Wade PR (2006) Worldwide distribution and abundance of killer whales. In: Estes JA, Demaster DP, Doak DF, Williams TM, Brownell RL Jr (eds) Whales, whaling and ocean ecosystems. University of California Press, Berkley, CA, p 145-162

Geraci JR, Lounsbury VJ (2005) Marine mammals ashore: a field guide for strandings, 2nd edn. National Aquarium in Baltimore, Baltimore, MD

* Geraci JR, Anderson DM, Timperi RJ, St. Aubin DJ, Early GA, Prescott JH, Mayo CA (1989) Humpback whales (Megaptera novaeangliae) fatally poisoned by dinoflagellate toxin. Can J Fish Aquat Sci 46:1895-1898

* Gibson AK, Raverty S, Lambourn DM, Huggins J, Magargal SL, Grigg ME (2011) Polyparasitism is associated with increased disease severity in Toxoplasma gondii-infected marine sentinel species. PLOS Negl Trop Dis 5:e1142

Gönener S, Bilgin S (2009) The effect of pingers on harbour porpoise, Phocoena phocoena bycatch and fishing effort in the turbot gill net fishery in the Turkish Black Sea coast. Turk J Fish Aquat Sci 9:151-157

Gray KN, Conklin RH (1974) Multiple births and cardiac anomalies in the bottle-nosed dolphin. J Wildl Dis 10: 155-157

Haelters J, Everaarts E (2011) Two cases of physical interaction between white-beaked dolphins (Lagenorhynchus albirostris) and juvenile harbor porpoises (Phocoena phocoena) in the Southern North Sea. Aquat Mamm 37: 198-201

Harper C (2002) Zoonotic diseases acquired from handling fish. Aquacult Mag 28:55-58

*Harris HS, Facemire P, Greig DJ, Colegrove KM and others (2011) Congenital neuroglial heterotopia in a neonatal 
harbor seal (Phoca vitulina richardsi) with evidence of recent exposure to polycyclic aromatic hydrocarbons. J Wildl Dis 47:246-254

*Hohn AA, Rotstein DS, Byrd BL (2013) Unusual mortality events in harbor porpoise strandings in North Carolina, 1997-2009. J Mar Biol 2013, Article ID 28989

Huggins JL, Raverty SA, Norman SA, Calambokidis J and others (2015) Increased harbor porpoise mortality in the Pacific Northwest, USA: understanding when higher levels may be normal. Dis Aquat Org 115:93-102

Jauniaux T, Petijean D, Brenez C, Borrens M and others (2002) Post-mortem findings and causes of death of harbor porpoises (Phocoena phocoena) stranded from 19902000 along the coastlines of Belgium and northern France. J Comp Pathol 126:243-253

Jepson PD, Baker JR, Kuiken T, Simpson VR, Kennedy S, Bennett PM (2000) Pulmonary pathology of harbour porpoises (Phocoena phocoena) stranded in England and Wales between 1990 and 1996. Vet Rec 146:721-728

Jepson PD, Bennett PM, Deaville R, Allchin CR, Baker JR, Law RJ (2005) Relationships between polychlorinated biphenyls and health status of harbor porpoises (Phocoena phocoena) stranded in the United Kingdom. Environ Toxicol Chem 24:238-248

Joblon MJ, Pokras MA, Morse B, Harry CT and others (2014) Body condition scoring system for delphinids based on short-beaked common dolphins (Delphinus delphis). J Mar Anim Ecol 7(2):5-13

Kennish MJ (2005) Environmental quality. In: Schwartz ML (ed) Encyclopedia of coastal science. Springer eBooks, Dordrecht, p 419-426

Koopman HN (1998) Topographical distribution of the blubber of harbor porpoises (Phocoena phocoena). J Mammal 79:260-270

Kucklick J, Schwacke L, Wells R, Hohn A and others (2011) Bottlenose dolphins as indicators of persistent organic pollutants in the western North Atlantic Ocean and Northern Gulf of Mexico. Environ Sci Technol 45: 4270-4277

Kuiken T (1996) Review of the criteria for the diagnosis of by-catch in cetaceans. In: Kuiken T (ed) Diagnosis of bycatch in cetaceans. Proceedings of the $2^{\text {nd }}$ ECS workshop on cetacean pathology. Euro Cet Soc Newsl 26 (Spec Issue). European Cetacean Society, Saskatoon, p 38-43

Kusewitt DF (2012) Neoplasia and tumor biology. In: McGavin MD, Zachary JF (eds) Pathologic basis of veterinary disease. Mosby-Elsevier, St. Louis, MO, p 289-320

Lafferty KD, Porter JW, Ford SE (2004) Are diseases increasing in the oceans? Annu Rev Ecol Evol Syst 35:31-54

Lair S, Measures LN, Martineau D (2016) Pathologic findings and trends in mortality in the beluga (Delphinapterus leucas) population of the St Lawrence Estuary, Québec, Canada, from 1983 to 2012. Vet Pathol 53: 22-36

Laist DW, Knowlton AR, Mead JG, Collet AS, Podesta M (2001) Collisions between ships and whales. Mar Mamm Sci 17:35-75

Larrat S, Measures L, Lair S (2012) Rake marks on a harbor porpoise (Phocoena phocoena) calf suggestive of a fatal interaction with an Atlantic white-sided dolphin (Lagenorhynchus acutus). Aquat Mamm 38:86-91

Lawson J, Benjamin S, Stenson G (2004) Harbour porpoise bycatch estimates for Newfoundland's nearshore cod fishery for 2002. Department of Fisheries and Oceans Canadian Science Advisory Secretariat Research Document
2004/066. www.isdm-gdsi.gc.ca/csas-sccs/applications/ publications/index-eng.asp

* Leopold MF, Begeman L, Heße E, van der Hiele J and others (2015) Porpoises: from predators to prey. J Sea Res 97 : $14-23$

Lesage V, Keays J, Turgeon S, Hurtubise S (2004) Incidental catches of harbour porpoises (Phocoena phocoena) in the gillnet fishery of the Estuary and Gulf of St. Lawrence in 2000-2002. Can Tech Rep Fish Aquat Sci 2552:37

McFee WE, Lipscomb TP (2009) Major pathologic findings and probable causes of mortality in bottlenose dolphins stranded in South Carolina from 1993 to 2006. J Wildl Dis 45:575-593

Measures L (2001) Lungworms of marine mammals. In: Samuel WM, Pybus MJ, Kocan AA (eds) Parasitic diseases of wild mammals, 2nd edn. Iowa State University Press, Ames, IA, p 288-300

Mersmann HJ (1974) Metabolic patterns in the neonatal swine. J Anim Sci 38:1022-1030

Muir DCG, Koczanski K, Rosenberg B, Béland P (1996) Persistent organochlorines in beluga whales (Delphinapterus leucas) from the St Lawrence River estuary - II. Temporal trends, 1982-1994. Environ Pollut 93:235-245

Nemiroff L, Wimmer T, Daoust PY, McAlpine DF (2010) Cetacean strandings in the Canadian Maritime provinces (1990-2008). Can Field Nat 124:32-44

Norman SA, Raverty S, Mclellan B, Pabst A and others (2004) Multidisciplinary investigation of stranded harbor porpoises (Phocoena phocoena) in Washington State with an assessment of acoustic trauma as a contributory factor (2 May-2 June 2003). NOAA Tech Memo NMFSNWR-34, US Dept Commerce

* Parsons ECM, Jefferson TA (2000) Post-mortem investigations on stranded dolphins and porpoises from Hong Kong waters. J Wildl Dis 36:342-356

Quinn PJ, Markey BJ, Carter ME, Donnelly WJ, Leonard FC (2002) Veterinary microbiology and microbial disease. Blackwell Science, Oxford

Read A (1990) Estimation of body condition in harbour porpoises, Phocoena phocoena. Can J Zool 68:1962-1966

Read AJ, Drinker P, Northridge S (2006) Bycatch of marine mammals in US and global fisheries. Conserv Biol 20: 163-169

Reif JS, Schaefer AM, Bossart GD (2015) Atlantic bottlenose dolphins (Tursiops truncatus) as a sentinel for exposure to mercury in humans: closing the loop. Vet Sci 2: 407-422

Rolland RM, Parks SE, Hunt KE, Castellote $\mathrm{M}$ and others (2012) Evidence that ship noise increases stress in right whales. Proc R Soc B 279:2363-2368

Scarratt M, Michaud S, Measures L, Starr M (2013) Phycotoxin analyses in St. Lawrence Estuary beluga. Department of Fisheries and Oceans Canadian Science Advisory Secretariat Research Document 2013/124. www.isdm-gdsi.gc.ca/csas-sccs/applications/publications/ index-eng.asp

Schoen FJ, Mitchell RN (2010) The heart. In: Kumar V, Abbas AK, Fausto N, Aster JC (eds) Robbins and Cotran pathologic basis of disease, 8th edn. Saunders-Elsevier, Philadelphia, PA, p 529-587

Schoonderwoerd M, Doige CE, Wobeser GA, Naylor JM (1986) Protein energy malnutrition and fat mobilization in neonatal calves. Can Vet J 27:365-371

* Siebert U, Wünschmann A, Weiss R, Frank H, Benke H, Frese K (2001) Post-mortem findings in harbour por- 
poises (Phocoena phocoena) from the German North and Baltic Seas. J Comp Pathol 124:102-114

Stone GS, Yoshinaga A (2000) Hector's dolphin (Cephalorhynchus hectori) calf mortalities may indicate new risks from boat traffic and habituation. Pac Conserv Biol 6:162-170

Trippel EA, Wang YJ, Strong MB, Carter LS, Conway JD (1996) Incidental mortality of harbor porpoises (Phocoena phocoena) by the gill-net fishery in the lower Bay of Fundy. Can J Fish Aquat Sci 53:1294-1300

Trippel EA, Strong MB, Terhune JM, Conway JD (1999) Mitigation of harbour porpoise (Phocoena phocoena) bycatch in the gillnet fishery in the lower Bay of Fundy. Can J Fish Aquat Sci 56:113-123

Van Bressem MF, Jepson P, Barrett T (1998) Further insight on the epidemiology of cetacean morbillivirus in the northeastern Atlantic. Mar Mamm Sci 14:605-613

Van Bressem MF, Raga JA, Di Guardo G, Jepson PD and others (2009) Emerging infectious diseases in cetaceans worldwide and the possible role of environmental stressors. Dis Aquat Org 86:143-157

Editorial responsibility: Sven Klimpel, Frankfurt, Germany van der Hoop JM, Moore MJ, Barco SG, Cole TVN and others (2013) Assessment of management to mitigate anthropogenic effects on large whales. Conserv Biol 27: 121-133

Van Parijs S, Corkeron PJ (2001) Boat traffic affects the acoustic behaviour of Pacific humpback dolphins (Sousa chinensis). J Mar Biol Assoc UK 81:533-538

Westgate AJ, Muir DCG, Gaskin DE, Kingsley MCS (1997) Concentrations and accumulation patterns of organochlorine contaminants in the blubber of harbour porpoises, Phocoena phocoena, from the coast of Newfoundland, the Gulf of St Lawrence and the Bay of Fundy/Gulf of Maine. Environ Pollut 95:105-119

Williams R, Gero S, Bejder L, Calambokidis J and others (2011) Underestimating the damage: interpreting cetacean carcass recoveries in the context of the Deepwater Horizon/BP incident. Conserv Lett 4:228-233

Wright AJ, Maar M, Mohn C, Nabe-Nielsen J and others (2013) Possible causes of a harbor porpoise mass stranding in Danish waters in 2005. PLOS ONE 8:e55553

Submitted: April 4, 2016; Accepted: November 11, 2016 Proofs received from author(s): January 4, 2017 